\title{
Pengaruh Faktor - Faktor Kinerja Individual Terhadap Efektivitas Penggunaan Sistem Informasi Imissu
}

\author{
Maria Mediatrix Ratna Sari ${ }^{1}$ \\ ${ }^{1}$ Fakultas Ekonomi dan Bisnis Universitas Udayana (Unud), Bali, Indonesia \\ email: maria.ratna65@unud.ac.id/ Telp: 088219194172
}

\begin{abstract}
ABSTRAK
Teknologi sistem informasi yang digunakan organisasi ditujukan untuk mempermudah individu dalam menyelesaikan tugasnya. Kemudahan suatu sistem dan pemanfaatan dalam pengelolaan sistem tersebut oleh pemakai sistem merupakan penentu dari keberhasilan suatu sistem. Tujuan penelitian ini adalah untuk mengetahui pengaruh faktor-faktor kinerja individual dosen akuntansi pada efektivitas penggunaan sistem informasi IMISSU. Populasi dalam penelitian ini adalah seluruh dosen Jurusan Akuntansi di Fakultas Ekonomi dan Bisnis Universitas Udayana Bali. Teknik penyampelan menggunakan purposive sampling dengan metode pengumpulan data menggunakan kuesioner. Teknik analisis yang digunakan adalah analisis regresi linier berganda. Hasil penelitian ini menunjukkan bahwa pengalaman, pelatihan, pendidikan, dan insentif berpengaruh positif terhadap efektivitas penggunaan IMISSU.Berdasarkan hasil penelitian disarankan bagi pihak Universitas Udayana sebagai penyedia sistem informasi IMISSU agar terus melakukan pembenahan dan pengembangan guna meningkatkan kinerja organisasi, danbagi pihak pengguna sistem informasi IMISSU diharapkan meningkatkan kemampuannya secara berkesinambungan untuk membangun kinerja yang lebih baik.
\end{abstract}

Kata kunci: Efektivitas Penggunaan IMISSU, Pengalaman Kerja, Pelatihan, Pendidikan, Insentif

\begin{abstract}
Information systems technology used by the organization is intended to facilitate the individual in completing the task. The ease of a system and utilization in management of the system by users of the system is a determinant of the success of a system. The purpose of this study is to determine the effect of individual performance factors of accounting lecturers on the effectiveness of the use of IMISSU information systems. Population in this research is all lecturer of Accounting Department at Faculty of Economics and Business Universitas Udayana Bali. Sampling technique using purposive sampling with data collection method using questionnaire. The analysis technique used is multiple linear regression analysis. The results of this study indicate that experience, training, education, and incentives have a positive effect on the effectiveness of IMISSU use.Based on the result of research, it is suggested for Udayana University as IMISSU information system provider in order to keep improving and improving to improve organizational performance, and for IMISSU users IMISSU information system is expected to improve their ability continuously to build better performance.
\end{abstract}

Keywords: Effectiveness of IMISSU Use, Work Experience, Training,Education, Incentives.

\section{PENDAHULUAN}

Perkembangan teknologi yang diiringi dengan perkembangan sistem informasi

berbasis teknologi mengalami kemajuan dan perkembangan yang sangat pesat. 
Kondisi lingkungan yang penuh dengan ketidakpastian mutlak memerlukan sistem informasi yang tepat, andal dan akurat. Suatu entitas yang unggul harus memiliki kualitas sistem informasi yang baik (Soudani, 2012). Sarana untuk meningkatkan kinerja entitas adalah adanya sistem teknologi informasi yang baik (Baig and Gururajan, 2011). Sistem teknologi informasi khususnya teknologi komputer mampu memperbaiki kinerja individual dalam suatu organisasi (Salehi, 2010). Penggunaan teknologi informasi memberikan manfaat yang sangat besar dalam suatu organisasi dan wajib dimanfaatkan serta menjadi kebutuhan yang sangat mutlak.

Standar kerja yang telah ditetapkan oleh organisasi mengacu pada kinerja individual anggota organisasi. Kinerja individual yang tinggi dapat meningkatkan kinerja organisasi secara keseluruhan. Bailey dan Pearson (1983) menyatakan kinerja individual berhubungan erat dengan tingkat imbalan dan kepuasan kerja yang dipengaruhi oleh keterampilan, kemampuan dan sifat-sifat individu itu sendiri. Sutermeister (1999) mengemukakan bahwa kinerja individual dapat dipengaruhi oleh dua faktor, yaitu faktor kemampuan dan faktor motivasi. Faktor kemampuan dinilai dari pengetahuan yang dilihat dari pendidikan, pengalaman, latihan, dan minat, serta faktor keterampilan yang dilihat dari kecakapan dan kepribadian. Faktor motivasi dinilai dari kondisi sosial, fisiologis (persepsi) dan egoistis (sifat egois). Robbins (2006:213) menambahkan motivasi merupakan proses yang ikut menentukan intensitas, arah, dan ketekunan individu dalam usaha mencapai sasaran. Motivasi dalam meningkatkan kinerja karyawan didukung dengan pemberian insentif yang cukup memuaskan. 
Teknologi sistem informasi yang digunakan organisasi ditujukan untuk mempermudah individu dalam menyelesaikan tugasnya. Kemudahan suatu sistem dan pemanfaatan dalam pengelolaan sistem tersebut oleh pemakai sistem merupakan penentu dari keberhasilan suatu sistem. Sistem informasi menjadi sarana penting guna mempercepat kerja karyawan dan meningkatkan kinerja karyawan serta menyediakan informasi akuntansi dan keuangan (Alsarayreh et al., 2011). Semakin luas dan kompleksnya aktivitas perekonomian mendorong setiap entitas untuk mampu mengelola aktivitas perekonomiannya dengan baik. Teknologi informasi memainkan peran kunci dalam pengelolaan organisasi, terutama dalam kaitannya dengan fungsi akuntansi (Efendi et.al. 2006).

Radityo (2007) menyatakan bahwa sistem informasi merupakan seperangkat komponen yang saling berhubungan mempunyai fungsi mengumpulkan, memproses, menyimpan, dan mendistribusikan informasi untuk mendukung pembuatan kepuasan dan pengawasan dalam organisasi. Menurut Heuer dan Travers (2010:42), dengan penggunaan perangkat elektronik maka perusahaan dapat melakukan penghematan sumber daya. Sistem Informasi merupakan modal dalam suatu organisasi yang berguna dalam menyiapkan informasi keuangan dan juga informasi yang diperoleh dari kegiatan pengumpulan dan pengelolaan transaksi (Baridwan, 2009). Dey (2007) menyatakan bahwa system informasi merupakan suatu struktur dalam suatu entitas, seperti perusahaan bisnis, yang mempekerjakan sumber daya fisik dan komponen lainnya untuk mengubah data ekonomi menjadi informasi, dengan tujuan memenuhi kebutuhan informasi dari berbagai pengguna informasi. Jadi sumber daya manusia 
pada perusahaan memiliki hubungan yang sangat erat dalam keberhasilan penggunaan teknologi dan sistem informasi pada perusahaan. Peningkatan kinerja individu akan lebih baik apabila ada kecocokan antara tugas yang sedang dikerjakan dengan teknologi yang diterapkan (Goodhue, 1995). Rahmawati (2008) menyatakan peningkatan kinerja individu karyawan di dalam melaksanakan tugas memiliki hubungan yang sangat erat antara kesesuaian tugas dengan kemampuan individual dalam menggunakan sistem teknologi informasi.

Alannita dan Suaryana (2014) mengatakan pemakai sistem informasi dituntut untuk memiliki kemampuan yang baik dalam mengoperasikan sistem sehingga dalam kegiatan operasional dan transaksi keuangan seorang pemakai sistem dapat bekerja dengan baik sehingga meningkatkan kinerja individual. Keberhasilan pemakai sistem teknologi informasi dalam suatu perusahaan sangat bergantung pada pemanfaatan, pengelolaan sistem dan kemudahan dalam penggunaan sistem tersebut (Edison, 2012). Dewi (2011) menyatakan bahwa tingkat pendidikan, pelatihan dan pengalaman kerja berpengaruh positif pada efektivitas sistem informasi akuntansi. Ceacilia (2012) menyatakan bahwa pelatihan dan tingkat pendidikan berpengaruh positif terhadap kinerja sistem informasi akuntansi. Berbeda dengan Komara (2006) yang menyatakan bahwa program pendidikan dan pelatihan tidak berpengaruh terhadap kinerja sistem informasi. Berdasarkan hasil penelitian sebelumnya yang tidak konsisten, maka dipandang penting untuk melanjutkan dan mengembangkan penelitian sebelumnya. 
Universitas Udayana (UNUD) sebagai salah satu Perguruan Tinggi Negeri di Bali berupaya membangun suatu sistem terintegrasi guna mewujudkan pengelolaan universitas yang sistematis dan transparan melalui penguatan di bidang teknologi informasi, yang dinamakan Integrated Management Information System The Strategic of Udayana (IMISSU). Namun dari awal penggunaannya, terjadi kontroversi persepsi dari penggunanya (khususnya Dosen), ada yang mencoba mengaplikasikannya namun ada juga yang antipati. Sampai saat ini sudah dua semester, IMISSU digunakan untuk mengevaluasi beban kinerja dosen, bahkan pada awal 2017 ini IMISSU juga akan digunakan untuk mengevaluasi beban kinerja pegawai. Adanya peningkatan kapasitas IMISSU dan adanya perdebatan penggunaannya, menimbulkan tanda tanya tentang efektivitas dari penggunaan IMISSU.

Penelitian ini menggunakan Pengalaman Kerja, Pelatihan, Tingkat Pendidikan, dan Insentif sebagai variabel bebas, serta efektivitas penggunaan IMISSU sebagai variabel terikat. Rumusan masalah dalam penelitian ini adalah apakah pengalaman kerja, pelatihan, tingkat pendidikan, dan insentif berpengaruh positif terhadap efektivitas penggunaan IMISSU? Tujuan penelitian ini adalah untuk mengetahui pengaruh pengalaman, pelatihan, tingkat pendidikan dan insentif pada efektivitas penggunaan sistem informasi IMISSU.

Iranto (2012) menyatakan bahwa Theory of Reasoned Action (TRA) atau teori tindakan bersama atau sering dikenal dengan teori tindakan beralasan yang dikembangkan oleh Ajen dan Fishbein (1980). TRA adalah suatu teori yang berhubungan dengan sikap dan perilaku individu dalam melaksanakan kegiatan. 
Secara singkat, praktik atau perilaku TRA dipengaruhi oleh niat, sedangkan niat dipengaruhi oleh sikap dan norma subyektif. Jogiyanto (2007) dalam Iranto (2012) mengatakan bahwa secara keseluruhan perilaku seseorang dapat dijelaskan dengan mempertimbangkan kepercayaannya, karena kepercayaan seseorang mewakili informasi yang mereka peroleh tentang dirinya sendiri dan dunia di sekitarnya. Teori ini membuat model perilaku seseorang sebagai suatu fungsi dari tujuan perilaku.

Widjajanto (2001:2) berpendapat bahwa sistem adalah suatu yang memiliki bagian-bagian yang saling berkaitan untuk dapat mencapai tujuan yang telah ditetapkan melalui tiga tahap yaitu input, proses dan output. Menurut Romney dan Steinbart (2003) dalam Citramurti (2012), sistem adalah serangkaian dari dua atau lebih komponen-komponen yang saling berhubungan dan berinteraksi untuk mencapai suatu tujuan. Sistem adalah sekelompok unsur yang erat hubungannya dengan unsur yang lain yang berfungsi bersama-sama untuk mencapai tujuan tertentu (Al-Eqab, 2013). Sistem diciptakan untuk menangani sesuatu yang berulang-ulang terjadi atau secara rutin terjadi (Mulyadi, 2001:31).

Gerald dalam Baridwan (2009) berpendapat bahwa sistem adalah suatu kerangka dari prosedur-prosedur yang saling berhubungan yang disusun sesuai dengan suatu skema yang menyeluruh, untuk melaksanakan suatu kegiatan atau fungsi utama dari perusahaan. Informasi merupakan hal yang fundamental dalam suatu organisasi khususnya dalam pengambilan keputusan. Informasi memiliki peran yang penting bagi sebuah organisasi untuk bertahan dalam pasar yang semakin berkembang (De Guinea et al. 2005). Kegunaan informasi adalah untuk 
mengurangi adanya ketidakpastian di dalam pengambilan keputuasan tentang suatu keadaan. Fakhri dan Wibowo (2005:5) mengungkapkan sistem informasi merupakan seperangkat komponen yang saling berhubungan yang berfungsi mengumpulkan, memproses, menyimpan dan mendistribusikan informasi untuk mendukung pembuatan keputusan dan pengawasan dalam organisasi.

Mulyadi (2001:30) menyatakan bahwa Sistem Informasi Akuntansi (SIA) adalah subsistem dari akuntansi manajemen yang terdapat dalam suatu organisasi yang mengelola data keuangan menjadi informasi keuangan yang memenuhi pemakai intern dan ekstern. Lain halnya dengan pendapat (Nicolaou, 2000) yang mengatakan bahwa sistem informasi merupakan sistem berbasis komputer yang didefinisikan suatu sistem yang meningkatkan kontrol dan meningkatkan korporasi dalam organisasi.

Menurut Cho dan Wong (1997) efektivitas sistem informasi akuntansi tergantung dari seberapa baik pengguna mengetahui sistem, layanan pendukung dari penyedia informasi dan kapasitas dari sistem itu sendiri. Efektivitas sistem dinilai berdasarkan sumbangannya pada proses pengambilan keputusan, mutu informasi akuntansi, evaluasi kinerja, pengendalian internal dan memfasilitasi transaksi perusahaan oleh (Sajady dan Nejad, 2008). Muhanna dan Stoel (2010:44) menyatakan dampak dan efektivitas dari teknologi informasi dalam perusahaan merupakan tema utama atau hal yang paling sering diteliti dalam bidang teknologi informasi, termasuk di dalamnya sistem informasi akuntansi.

IMISSU mulai dibangun oleh Unit Sumber Daya Informasi (USDI) Universitas Udayana pada tahun 2015, merupakan suatu sistem terintegrasi untuk 
mewujudkan pengelolaan universitas yang sistematis dan transparan melalui penguatan di bidang teknologi informasi. Sistem IMISSU(Integrated Management Information System the Strategic of Udayana), yaitu pengembangan, penataan dan pengintegrasian sistem informasi ke dalam suatu layanan SSO (Single Sign On), baik dalam konteks pengelolaan user, integrasi sistem informasi dan data di level database dan integrasi bisnis proses (https://www.unud.ac.id/in/berita563---SOSIALISASI-IMISSU.html).

Cascio (2001:260) pengalaman adalah suatu faktor untuk menilai seberapa lama seseorang mengetahui atau bertukar pengetahuan dengan orang lain untuk bisa melaksanakan pekerjaannya secara efektif. Pengalaman menentukan keterampilan individu dalam melaksanakan tugas tertentu. Pengalaman dapat berdampak positif atau negatif terhadap kemampuan kerja individu. Sikap merupakan perpaduan antara masa lampau dengan keadaan lingkungan masa kini. Mangkuprawira (2003:135) mengatakan bahwa pelatihan merupakan sebuah proses yang mengajarkan pengetahuan dan keahlian tertentu serta sikap, agar karyawan semakin terampil dan mampu melakukan tanggung jawabnya dengan semakin baik serta sesuai dengan standar. Menurut Syarfarudin (2001), pendidikan adalah usaha untuk meningkatkan pengetahuan seseorang. Pendidikan sebagai optimalisasi sumber daya manusia yang cenderung lebih bersifat formal menyangkut antisipasi kemampuan dan keahlian individu yang harus dipersiapkan bagi kepentingan jabatan yang akan datang untuk mengantisipasi perubahan yang mungkin terjadi tanpa direncanakan ataupun yang direncanakan. Insentif adalah suatu sarana memotivasi berupa materi yang diberikan, sebagai suatu stimuli 
ataupun pendorong, dengan sengaja kepada individu untuk menimbulkan semangat yang besar dalam dirinya guna meningkatkan produktivitas kerja dalam organisasi (Gorda, 2004:141).

Pengalaman merupakan suatu proses atau tingkat penguasaan pengetahuan serta keterampilan seseorang dalam pekerjaannya yang dapat diukur dari masa kerja, tingkat pengetahuan dan keterampilan yang dimilikinya. Manulang (1984:25) mengatakan Pengalaman adalah proses pembentukan pengetahuan atau keterampilan tentang metode suatu pekerjaan karena keterlibatan karyawan tersebut dalam pelaksanaan tugas pekerjaan. Dewi (2011) dan Ali (2011) menyatakan bahwa pengalaman berpengaruh positif dan signifikan terhadap efektivitas sistem informasi akuntansi. Berdasarkan penjelasan tersebut, maka dirumuskan hipotesis sebagai berikut.

$\mathrm{H}_{1}$ : Pengalaman berpengaruh positif pada efektivitas penggunaan IMISSU.

Pelatihan merupakan suatu kegiatan yang bertujuan untuk memperbaiki dan mengembangkan sikap, tingkah laku keterampilan, dan pengetahuan dari karyawannya sesuai dengan keinginan perusahaan. Pelatihan sangat diperlukan karena adanya ketidakseimbangan antara keterampilan yang dimiliki individu dan keterampilan yang dibutuhkan untuk menempati posisi baru (Wibowo, 2012:442). Program pelatihan yang dirancang perusahaan bertujuan agar karyawannya mampu menciptakan kinerja yang lebih baik. Gomes (2003:197) mengatakan bahwa pelatihan adalah setiap usaha untuk memperbaiki performansi pekerja pada suatu pekerjaan tertentu yang sedang menjadi tanggung jawabnya, atau satu pekerjaan yang ada kaitannya dengan pekerjaannya. Erayanti (2012) dan Holmes 
(1988) menyatakan bahwa pelatihan kerja berpengaruh positif terhadap kinerja pengguna sistem informasi akuntansi. Berdasarkan penjelasan tersebut, maka dirumuskan hipotesis sebagai berikut.

$\mathrm{H}_{2}$ : Pelatihan berpengaruh positif pada efektivitas penggunaan IMISSU.

Pendidikan merupakan proses pembentukan diri dan penentuan sikap yang bersamaan dengan proses pertumbuhan atau perkembangan kepribadian seseorang. Carter (1997:23) mengatakan pendidikan merupakan proses perkembangan kecakapan seseorang dalam bentuk sikap dan perilakunya dalam masyarakat. Wahyu (2011) dan Ceacilia (2012) menyatakan bahwa tingkat pendidikan berpengaruh positif terhadap efektivitas sistem informasi akuntansi. Berdasarkan penjelasan tersebut, maka dirumuskan hipotesis sebagai berikut.

$\mathrm{H}_{3}$ : Tingkat pendidikan berpengaruh positif pada efektivitas penggunaan IMISSU. Insentif merupakan tambahan kompensasi di luar gaji atau upah yang diberikan perusahaan kepada karyawannya. Insentif merupakan dorongan atau rangsangan yang diberikan kepada karyawan agar karyawannya mau memberikan kinerja dan hasil terbaik bagi perusahaan. Hasibuan (2008:117) mengatakan bahwa insentif adalah tambahan balas jasa yang diberikan kepada karyawan tertentu yang prestasinya di atas prestasi standar. Insentif ini merupakan alat yang dipergunakan untuk mendukung prinsip adil dalam pemberian kompensasi. Insentif merupakan imbalan langsung yang dibayarkan kepada karyawan karena prestasi melebihi standar yang ditentukan. Cascio (1992:377) mengatakan insentif merupakan variabel penghargaan yang diberikan kepada individu dalam suatu kelompok, yang diketahui berdasarkan perbedaan dalam mencapai hasil kerja. 
Erayanti (2012) dan Rolasmana (2013) menyatakan bahwa insentif berpengaruh positif terhadap efektivitas penggunaan sistem informasi akuntansi. Berdasarkan penjelasan tersebut, maka dirumuskan hipotesis sebagai berikut.

$\mathrm{H}_{4}$ : Insentif berpengaruh positif pada efektivitas penggunaan IMISSU.

\section{METODE PENELITIAN}

Pendekatan yang digunakan dalam penelitian ini adalah pendekatan kuantitatif berbentuk asosiatif, yang menjelaskan hubungan antara dua variabel atau lebih (Sugiyono : 2013: 55), dengan kerangka konseptual sebagai berikut.

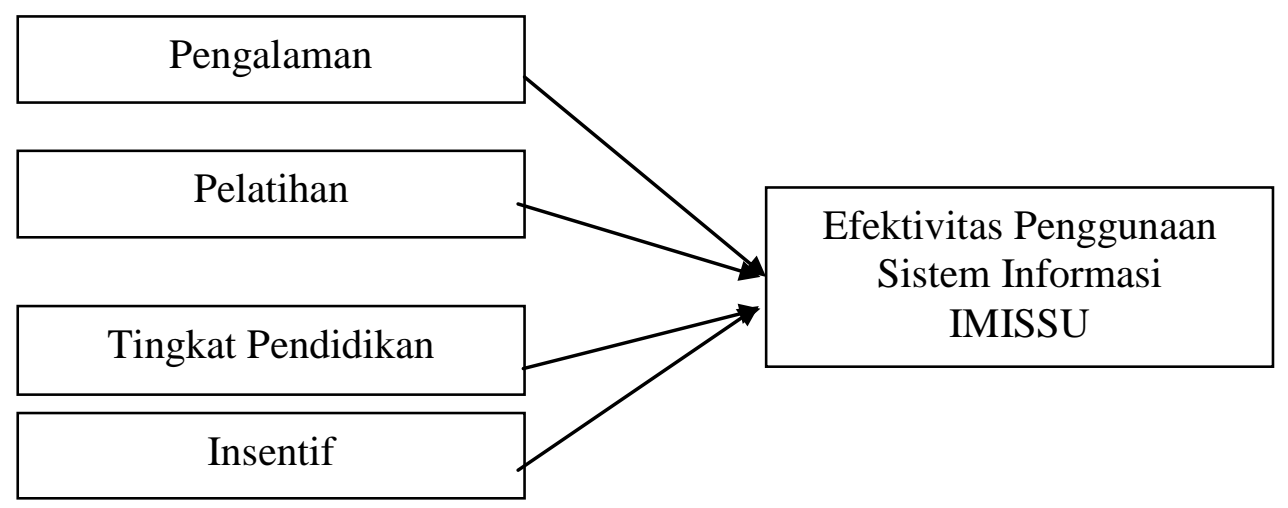

\section{Gambar 1. Desain Penelitian}

Penelitian ini mengambil lokasi pada Fakultas Ekonomi dan Bisnis (FEB) Universitas Udayana, Bali. FEB merupakan salah satu fakultas yang memberikan kontribusi penerimaan terbesar di lingkungan Universitas Udayana. Objek penelitian yang digunakan dalam penelitian ini adalah efektivitas penggunaan sistem informasi IMISSU. 
Variabel bebas yang digunakan dalam penelitian ini adalah; Pengalaman yang dimaksud adalah intensitas kegiatan yang pernah dikerjakan oleh individu pada suatu bidang yang ditekuni. Proses yang pernah dialami oleh individu yang berkaitan dengan keterampilan dan pembentukan pengetahuan akibat keterlibatan individu dalam melaksanakan suatu pekerjaan dapat pula dikatakan sebagai pengalaman. Indikator diadopsi dari Dewi (2011) dengan modifikasi.

Pelatihan merupakan sebagian kegiatan yang dilakukan individu untuk memperbaiki kemampuan kerja yang dimiliki tiap individu berhubungan dengan aktivitas yang akan dilakukan selama bekerja agar tujuan organisasi dapat tercapai. Indikator diadopsi dari Dewi (2011) dengan modifikasi.

Tingkat pendidikan adalah jenjang pendidikan terakhir yang telah ditempuh dan diselesaikan oleh individu. Jenjang pendidikan dikelompokan dalam 2 kategori jenjang pendidikan formal, yaitu S2 dengan skor 1, dan S3 dengan skor 2.

Insentif adalah dorongan yang diberikan kepada individu untuk meningkatkan kualitas kinerjanya agar mampu menjadi lebih baik atau meningkat. Indikator diadopsi dari Erayanti (2012).

Variabel terikat dalam penelitian ini adalah efektivitas penggunaan sistem informasi IMISSU, yang merupakan suatu kondisi yang menyatakan apakah pengguna sistem berhasil atau tidak dalam mengimplementasikan sistem informasi IMISSU. Indikator diadopsi dari Dewi (2011) dengan modifikasi, dan diukur menggunakan skala likert 4 poin dengan nilai 1 (sangat tidak setuju) sampai 4 (sangat setuju). 
Penelitian ini menggunakan data kuantitatif yang berasal dari data kualitatif yang dikuantitatifkan dengan bantuan Skala Likert. Sumber data dalam penelitian ini adalahdata primer berupa pernyataan responden dalam menjawab kuesioner.Populasi dalam penelitian ini adalah seluruh dosen Jurusan Akuntansi Fakultas Ekonomi dan Bisnis Universitas Udayana, yang berjumlah 62 orang. Sampel ditentukan berdasarkan metode nonprobability sampling dengan teknik purposive sampling, dengan kriteria 1) terdaftar sebagai dosen aktif, 2) telah menggunakan sistem informasi IMISSU lebih dari sekali (satu semester). Metode pengumpulan data menggunakan teknik survei dengan kuesioner. Analisis statistik deskriptif memberikan gambaran atau deskripsi suatu data yang dilihat dari besarnya nilai minimum, maksimum, mean, modus, dan simpangan baku (standard deviation) dengan $\mathrm{N}$ merupakan banyaknya responden penelitian.

Uji instrumen penelitian terdiri dari uji reliabilitas dan uji validitas. Uji Validitas, dilakukan dengan menghitung korelasi antara skor masing-masing butir pertanyaan dengan total skor masing-masing butir pertanyaan dengan total skor dengan bantuan SPSS versi 22. Syarat minimum kuesioner untuk memenuhi validitas adalah jika $\mathrm{r}$ bernilai minimal 0,3 (Sugiyono, 2013:115). Jika korelasi item terhadap skor total lebih besar dari $\mathrm{r}$ kritis $(0,3)$ maka instrumen penelitian tersebut valid. Uji Reliabilitas, menggunakan uji statistik Cronbach Alpha, dimana Item-item pertanyaan atau pernyataan dapat dikatakan reliabel apabila memberikan nilai Cronbach Alpha > 0,60(Ghozali, 2009:33).

Pengujian asumsi klasik yang digunakan dalam penelitian ini meliputi uji normalitas, uji multikolinearitas dan uji heteroskedastisitas. Menurut Ghozali (2009: 147) model regresi yang baik merupakan data yang terdistribusi normal. 
Jika Sig (2-tailed) lebih besar dari level of significant yang dipakai yaitu 0,05 (5 persen), maka dapat disimpulkan bahwa residual yang dianalisis berdistribusi normal. Utama (2010:106) menyebutkan bahwa pengujian multikolinieritas digunakan untuk menguji apakah dalam model regresi ditemukan adanya korelasi antara variabel bebas. Multikoleniaritas dapat dilihat dari nilai tolerance lebih dari $10 \%$ atau VIF kurang dari 10, maka dikatakan tidak ada multikoleniaritas. Uji heteroskedastisitas dilakukan untuk menguji apakah dalam model regresi terjadi ketidaksamaan varian dari residual pengamatan satu ke pengamatan lainnya (Utama, 2010: 107). Pengujian ini dilakukan dengan uji Glejser, Jika signifikansi t dari hasil meregresi nilai absolute residual terhadap variabel bebas lebih dari 0,05 maka model regresi tidak mengandung heteroskedastisitas.

Teknik analisis data yang digunakan dalam penelitian ini adalah teknik analisis regresi linear berganda yang diuji dengan tingkat signifikansi 0,05. Menurut Sugiyono (2013:277) analisis regresi linear berganda digunakan untuk mengetahui atau memperoleh gambaran mengenai pengaruh variabel bebas terhadap variabel terikat. Model regresi linear berganda tersebut diformulasikan sebagai berikut.

$$
Y=\alpha+\beta_{1} X_{1}+\beta_{2} X_{2}+\beta_{3} X_{3}+\beta_{4} X_{4}+\varepsilon
$$

Keterangan :

$$
\begin{array}{ll}
\mathrm{Y} & =\text { Efektivitas penggunaan system informasi IMISSU } \\
\alpha & =\text { konstanta } \\
\beta_{1} & =\text { koefisien regresi pengalaman } \\
\beta_{2} & =\text { koefisien regresi pelatihan } \\
\beta_{3} & =\text { koefisien regresi tingkat pendidikan } \\
\beta_{4} & =\text { koefisien regresi insentif } \\
\mathrm{X}_{1} & =\text { pengalaman } \\
\mathrm{X}_{2} & =\text { pelatihan }
\end{array}
$$




$$
\begin{array}{ll}
\mathrm{X}_{3} & =\text { tingkat pendidikan } \\
\mathrm{X}_{4} & =\text { insentif } \\
\varepsilon & =\text { standar eror }
\end{array}
$$

Koefisien determinasi mengukur seberapa jauh kemampuan model dalam menerangkan variabel dependen, Ghozali (2009:97). Nilai $\left(\mathrm{R}^{2}\right)$ yang kecil berarti kemampuan variabel-variabel independen dalam menjelaskan variabel dependen sangat terbatas. Nilai $\left(\mathrm{R}^{2}\right)$ yang mendekati satu berarti variabel-variabel independen memberikan hampir semua informasi yang dibutuhkan untuk memprediksi variabel-variabel dependen.

Uji F digunakan untuk melihat kelayakan model dalam penelitian, yang digunakan sebagai alat analisis untuk menguji pengaruh variabel bebas terhadap variabel terikat. Uji $\mathrm{F}$ dilakukan dengan melihat nilai signifikansi pada tabel ANOVA. Apabila nilai signifikansi ANOVA $<0,05$ maka model penelitian dikatakan layak digunakan sebagai model regresi.

Uji parsial digunakan untuk menunjukkan pengaruh satu variabel bebas secara individu terhadap variabel terikat. Uji parsial dilakukan dengan melihat nilai signifikansi t masing-masing variabel. Jika nilai signifikansi $\mathrm{t} \leq 0,05$, berarti variabel bebas secara individual mempunyai pengaruh yang signifikan terhadap variabel terikat $\left(\mathrm{H}_{0}\right.$ ditolak dan $\mathrm{H}_{1}$ diterima).

\section{HASIL DAN PEMBAHASAN}

Pengumpulan data menggunakan kuesioner dengan responden dosen Jurusan Akuntansi Fakultas Ekonomi dan Bisnis yang berjumlah 62 orang dosen, meliputi 54 dosen aktif, 7 dosen tugas belajar, 1 dosen belum menggunakan IMISSU lebih dari 1 semester, sehingga kuesioner yang disebar sebanyak 54 kuesioner. 
Tabel 1.

Rincian Penyebaran dan Pengembalian Kuesioner

\begin{tabular}{lc}
\hline \multicolumn{1}{c}{ Keterangan } & Jumlah \\
\hline Kuesioner yang disebar & 54 \\
Kuesioner yang tidak dikembalikan & 3 \\
Kuesioner yang dikembalikan & 51 \\
Kuesioner yang gugur (tidak lengkap) & 2 \\
Kuesioner yang digunakan & 49 \\
Tingkat pengembalian & $94,44 \%$ \\
Tingkat pengembalian yang digunakan & $90,74 \%$ \\
\hline
\end{tabular}

Sumber : Data diolah, 2017

Tabel 1 menunjukkan tingkat respon 90,74\% dengan 49 kuesioner yang digunakan, dari 54 kuesioner yang disebar terdapat 3 kuesioner tidak kembali dan 2 kuesioner tidak lengkap.Karakteristik responden penelitian tersaji pada Tabel 2 yang menunjukkan karakteristik responden berdasarkan gender, pendidikan, umur, dan lama bekerja.

Tabel 2.

Karakteristik Responden

\begin{tabular}{llcc}
\hline \multicolumn{1}{c}{ Keterangan } & Jumlah & Persentase (\%) \\
\hline Gender & Laki-laki & 32 & $65,30 \%$ \\
& Perempuan & 17 & $34,70 \%$ \\
Pendidikan & S2 & 21 & $42,86 \%$ \\
& S3 & 28 & $57,14 \%$ \\
& $30-39$ tahun & 6 & $12,24 \%$ \\
& $40-49$ tahun & 8 & $16,33 \%$ \\
& $50-59$ tahun & 29 & $59,19 \%$ \\
Lama & $60-69$ tahun & 6 & $12,24 \%$ \\
Bekerja & $0-9$ tahun & 3 & $6,12 \%$ \\
& $10-19$ tahun & 11 & $22,45 \%$ \\
& $20-29$ tahun & 26 & $53,06 \%$ \\
& $30-39$ tahun & 9 & $18,37 \%$ \\
\hline
\end{tabular}

Sumber : Data diolah, 2017

Statistik deskriptif memberikan gambaran besarnya nilai minimum, maksimum, mean, modus, dan simpangan baku (standard deviation) tersaji dalam 
Tabel 3.

Statistik Deskriptif

\begin{tabular}{lrrrrr}
\hline & N & Minimum & Maximum & Mean & Std. Deviation \\
\hline PM & 49 & 3.20 & 3.80 & 3.4531 & .19051 \\
PT & 49 & 2.83 & 3.83 & 3.2151 & .32203 \\
PD & 49 & 1.00 & 2.00 & 1.5714 & .50000 \\
IS & 49 & 2.60 & 4.00 & 3.0571 & .29155 \\
EPSII & 49 & 2.50 & 3.70 & 3.2000 & .31885 \\
Valid N (listwise) & 49 & & & &
\end{tabular}

Hasil analisis statistik deskriptif dalam Tabel 3 menunjukkan bahwa pengalaman (PM), memiliki nilai minimum 3,20; nilai maksimum 3,80, serta nilai rata-rata3,4531 yang artinya sebagian besar responden menjawab sangat setuju untuk masing-masing item pernyataan $\mathrm{X}_{1}$; pelatihan $(\mathrm{PT})$, memiliki nilai minimum 2,83 dan nilai maksimum 3,83 yang artinya sebagian besar responden menjawab setuju dan sangat setuju untuk masing-masing item pernyataan $\mathrm{X}_{2}$; pendidikan (PD), memiliki nilai minimum 1,00 dan nilai maksimum 2,00 yang menunjukkan sebagian responden berpendidikan Sarjana Strata 1 dan Strata 2; insentif (IS), memiliki nilai minimum 2,60 dan nilai maksimum 4,00 yang artinya sebagian besar responden menjawab stuju dan sangat setuju untuk masing-masing item pernyataan X4; efektivitas Penggunaan Sistem Informasi IMISSU (EPSII) memiliki nilai minimum 2,50 dan nilai maksimum 3,70 yang artinya sebagian responden menjawab tidak setuju, setuju dan sangat setuju untuk masing-masing item pernyataan $\mathrm{Y}$.

Pengujian validitas menggunakan nilai pearson correlationtersaji menunjukkan bahwa instrumen yang digunakan valid. Butir pernyataan dianggap valid bila nilai pearson correlation lebih besar dari 0,3 (Sugiyono, 2013:115).Pengujian reliabilitas tersaji pada Tabel 5 yang menunjukkan bahwa 
instrumen yang digunakan reliabel. Suatu instrumen penelitian dikatakan reliabel jika nilai cronbach's alpha lebih besar dari 0,6 (Ghozali, 2009:33).

Hasil uji normalitas Kolmogorov - Smirnov Testdengan nilai Asymp. Sig. (2tailed) sebesar 0,879 >0,05 yang menunjukkan bahwa variabel pengalaman, pelatihan, pendidikan, insentif dan efektivitas penggunaan sistem informasi IMISSU berdistribusi normal. Uji multikoleniaritas menunjukkan bahwa nilai tolerance pada setiap variabel bebas lebih besar dari $10 \%(0,1)$ dan nilai VIF pada setiap variabel bebas lebih kecil dari 10, yang berarti bahwa tidak ada multikoleniaritas pada variabel bebas. Hasil uji heteroskedastisitas menunjukkan bahwa nilai signifikansi pada masing-masing variabel bebas lebih dari $0,05(5 \%)$ yang berarti model regresi bebas dari heteroskedastisitas.

Tabel 4.

Hasil Regresi Linier Berganda

\begin{tabular}{lccccc}
\hline \multicolumn{1}{c}{ Model } & Unstandardized Coefficients & $\begin{array}{c}\text { Standardized } \\
\text { Coefficients }\end{array}$ & t & Sig \\
\cline { 2 - 5 } & \multicolumn{1}{c}{$\boldsymbol{\beta}$} & Std.Error & Beta & & \\
\hline Constant) & $-0,220$ & 0,524 & & $-0,421$ & 0,676 \\
Pengalaman (PM) & 0,410 & 0,179 & 0,245 & 2,295 & 0,027 \\
Pelatihan (PT) & 0,231 & 0,097 & 0,233 & 2,385 & 0,021 \\
Pendidikan (PD) & 0,176 & 0,068 & 0,277 & 2,577 & 0,013 \\
Insentif (IS) & 0,322 & 0,113 & 0,294 & 2,851 & 0,007 \\
\hline \multicolumn{1}{c}{ Sumber: Data }
\end{tabular}

Sumber: Data diolah, 2017

Berdasarkan hasil uji regresi (pada Tabel 4), model regresi dalam penelitian ini

adalah sebagai berikut.

$$
\mathrm{Y}=-0,220+(0,410 \mathrm{PM})+(0,231 \mathrm{PT})+(0,176 \mathrm{PD})+(0,322 \mathrm{IS})+\varepsilon
$$


Persamaan model regresi menunjukkan bahwa nilai konstanta $(\alpha)$ sebesar -0,220 artinya apabila variabel-variabel bebas pengalaman (PM), pelatihan (PT), pendidikan (PD) dan insentif (IS) diasumsikan tidak mengalami perubahan (konstan) maka nilai EPSII (efektivitas penggunaan sistem informasi IMISSU) adalah sebesar $-0,220$ satuan.Nilai koefisien regresi pengalaman (PM) sebesar 0,410 artinya apabila pengalaman (PM) naik sebesar satu satuan, sementara PT, PD dan IS diasumsikan tetap, maka EPSII akan meningkat sebesar 0,410.Nilai koefisien regresi pelatihan (PT) sebesar 0,231artinya apabila pelatihan (PT) naik sebesar satu satuan, sementara PM, PD dan IS diasumsikan tetap, maka EPSII akan meningkat sebesar 0,231 satuan. Nilai koefisien pendidikan (PD) sebesar 0,176 artinya apabila pendidikan (PD) naik sebesar satu satuan, maka EPSII akan meningkat sebesar 0,176 satuan. Nilai koefisien insentif (IS) sebesar 0,322 artinya apabila insentif (IS) naik sebesar satu satuan, maka EPSII akan meningkat sebesar 0,322 satuan.

Berdasarkan hasil uji menunjukkan nilai Adjusted $R$ Square sebesar 0,813 berarti bahwa efektivitas penggunaan sistem informasi IMISSU dipengaruhi oleh pengalaman, pelatihan, pendidikan dan insentif sebesar $81,3 \%$ dan sisanya sebesar $18,7 \%$ dipengaruhi oleh variabel lainnya yang tidak dimasukkan ke dalam model.Hasil uji kelayakan model menunjukan nilai $\mathrm{F}$ hitung sebesar 47,901 dengan signifikansi 0,000 . Hal ini berarti bahwa pengalaman, pelatihan, pendidikan dan insentif layak digunakan untuk memprediksi efektivitas penggunaan sistem informasi IMISSU, sehingga pengujian hipotesis penelitian dapat dilakukan. 
Berdasarkan hasil uji hipotesis (uji t) pada Tabel 5.9menunjukkan bahwa pengaruh pengalaman (PM) terhadap efektivititas penggunaan sistem informasi IMISSU (EPSII) dengan tingkat signifikansi thitung sebesar 0,027 lebih kecil dari $\alpha=0,05$, maka $\mathrm{H} 0$ ditolak dan $\mathrm{H} 1$ diterima. Hal ini membuktikan bahwa pengalaman berpengaruh positif terhadap efektivitas penggunaan sistem informasi IMISSU. Semakin tinggi pengalaman maka semakin efektif penggunaan sistem informasi IMISSU.Pengaruh pelatihan (PT) terhadap efektivitas penggunaan sistem informasi IMISSU (EPSII) menunjukkan tingkat signifikansi t hitung sebesar 0,021 lebih kecil dari $\alpha=0,05$, maka H0 ditolak dan H1 diterima. Hal ini membuktikan bahwa pelatihan berpengaruh positif terhadap efektivitas penggunaan sistem informasi IMISSU. Semakin tinggi pelatihan maka semakin efektif penggunaan sistem informasi IMISSU.Pengaruh pendidikan (PD) terhadap efektivitas penggunaan sistem informasi IMISSU (EPSII) dengan tingkat signifikansi t hitung sebesar 0,013 lebih kecil dari $\alpha=0,05$, maka H0 ditolak dan H1 diterima. Hal ini membuktikan bahwa pendidikan berpengaruh positif terhadapefektivitas penggunaan sistem informasi IMISSU. Semakin tinggi pendidikan maka semakin efektif penggunaan sistem informasi IMISSU.Pengaruh insentif (IS) terhadap efektivitas penggunaan sistem informasi IMISSU (EPSII) menunjukkan tingkat signifikansi t hitung sebesar 0,007 lebih kecil dari $\alpha=0,05$, maka H0 ditolak dan $\mathrm{H} 1$ diterima. Hal ini membuktikan bahwa insentif berpengaruh positif terhadap efektivitas penggunaan sistem informasi IMISSU.Semakin tinggi insentif yang diberikan maka semakin efektif penggunaan sistem informasi IMISSU. 
Pengalaman merupakan suatu proses atau tingkat penguasaan pengetahuan serta keterampilan seseorang dalam pekerjaannya yang dapat diukur dari masa kerja, tingkat pengetahuan dan keterampilan yang dimilikinya. Manulang (1984:25) mengatakan Pengalaman adalah proses pembentukan pengetahuan atau keterampilan tentang metode suatu pekerjaan karena keterlibatan karyawan tersebut dalam pelaksanaan tugas pekerjaan. Theory of Reasoned Action (TRA) menjelaskan hubungan sikap dan perilaku individu dalam melaksanakan kegiatan sebagai suatu fungsi dari tujuan perilaku. Perilaku seseorang dapat dijelaskan dengan mempertimbangkan kepercayaannya atas kemampuan yang diperoleh dari pengalaman pribadinya.

Hasil penelitian menunjukkan bahwa semakin banyak pengalaman yang dimiliki, maka semakin tinggi keinginan seseorang untuk memanfaatkan sistem informasi yang tersedia, guna meningkatkan kinerjanya. Hal ini mendukung penelitian Dewi (2011) dan Ali (2011) yang menyatakan bahwa pengalaman berpengaruh positif terhadap efektivitas sistem informasi akuntansi.

Pelatihan merupakan suatu kegiatan yang bertujuan untuk memperbaiki dan mengembangkan sikap, tingkah laku keterampilan, dan pengetahuan dari karyawannya sesuai dengan keinginan perusahaan guna menciptakan kinerja karyawan yang lebih baik. Menurut Gomes (2003:197), pelatihan adalah usaha untuk memperbaiki performansi pekerja pada suatu pekerjaan tertentu yang sedang menjadi tanggung jawabnya, atau satu pekerjaan yang ada kaitannya dengan pekerjaannya. Dengan adanya pelatihan akan menuntun dan mendorong 
pemanfaatan sistem informasi yang tersedia guna meningkatkan kinerja individu dan kinerja organisasi. Hal ini mendukung Theory of Reasoned Action (TRA) atau teori tindakan bersama atau teori tindakan beralasan yang berhubungan dengan sikap dan perilaku individu dalam melaksanakan kegiatan. Teori ini membuat model perilaku seseorang sebagai suatu fungsi dari tujuan perilaku.

Hasil penelitian menunjukkan bahwa pelatihan berpengaruh positif terhadap efektivitas penggunaan sistem informasi IMISSU. Semakin banyak pelatihan pemanfaatan sistem informasi IMISSU diberikan, akan semakin efektif penerapan sistem informasi IMISSU, sehingga penilaian atas kemampuan sistem informasi dapat dilakukan. Hasil penelitian ini mendukung penelitianErayanti (2012) dan Holmes (1988) yang menyatakan bahwa pelatihan kerja berpengaruh positif terhadap kinerja pengguna sistem informasi akuntansi.

Pendidikan merupakan proses pembentukan diri dan penentuan sikap yang bersamaan dengan proses pertumbuhan atau perkembangan kepribadian seseorang. Carter (1997:23) mengatakan pendidikan merupakan proses perkembangan kecakapan seseorang dalam bentuk sikap dan perilakunya dalam masyarakat. Theory of Reasoned Action (TRA) menjelaskan bahwa secara keseluruhan perilaku individu dapat dijelaskan dengan mempertimbangkan kepercayaannya, karena kepercayaan individu mewakili informasi yang diperolehnya tentang dirinya sendiri dan dunia di sekitarnya. Semakin tinggi pendidikan individu, semakin tinggi rasa percaya dirinya atas kemampuan yang dimilikinya serta dukungan pandangan positif dari lingkungannya, hal ini akan meningkatkan niat individu untuk menunjukkan kemampuannya dengan 
memanfaatkan sistem informasi yang ada, sehingga pemanfaatan sistem informasi IMISSU akan lebih efektif. Hasil penelitian ini mendukung pernyataan Wahyu (2011) dan Ceacilia (2012), yang menyatakan bahwa tingkat pendidikan berpengaruh positif terhadap efektivitas sistem informasi akuntansi.

Insentif merupakan tambahan kompensasi di luar gaji atau upah yang diberikan perusahaan kepada karyawannya. Insentif merupakan dorongan atau rangsangan yang diberikan kepada karyawan agar karyawannya mau memberikan kinerja dan hasil terbaik bagi perusahaan. Cascio (1992:377) mengatakan insentif merupakan variabel penghargaan yang diberikan kepada individu dalam suatu kelompok, yang diketahui berdasarkan perbedaan dalam mencapai hasil kerja. Theory of Reasoned Action (TRA) adalah suatu teori yang berhubungan dengan sikap dan perilaku individu dalam melaksanakan kegiatan. Secara singkat, praktik atau perilaku TRA dipengaruhi oleh niat, sikap dan norma subyektif. Teori ini membuat model perilaku seseorang sebagai suatu fungsi dari tujuan perilaku. Perilaku individu sangat dipengaruhi oleh imbalan yang akan diperolehnya. Salah satu kegunaan yang difasilitasi oleh sistem informasi IMISSU adalah penghitungan remunerasi yang didasarkan atas kinerja yang dicapai, hal ini akan mendorong pemanfaatannya oleh seluruh dosen dan pegawai di lingkungan Universitas Udayana.Hasil penelitian menunjukkan bahwa insentif berpengaruh positif terhadap efektivitas penggunaan sistem informasi IMISSU, hal ini mendukung penelitian Erayanti (2012) dan Rolasmana (2013). Semakin tinggi insentif yang ditawarkan dalam pemanfaatan sistem informasi IMISSU, maka semakin efektif penggunaan sistem informasi tersebut. 


\section{SIMPULAN}

Berdasarkan hasil analisis dan pembahasan diperoleh simpulan bahwa pengalaman, pelatihan, pendidikan, dan insentif berpengaruh positif terhadap efektivitas penggunaan sistem informasi IMISSU. Semakin banyak pengalaman yang dimiliki, maka semakin tinggi keinginan seseorang untuk memanfaatkan sistem informasi yang tersedia, guna meningkatkan kinerjanya.Semakin banyak pelatihan pemanfaatan sistem informasi IMISSU diberikan, akan semakin efektif penerapan sistem informasi IMISSU. Semakin tinggi pendidikan individu, semakin tinggi niat individu untuk menunjukkan kemampuannya dengan memanfaatkan sistem informasi yang ada, sehingga pemanfaatan sistem informasi IMISSU akan lebih efektif.Semakin tinggi insentif yang ditawarkan dalam pemanfaatan sistem informasi IMISSU, maka semakin efektif penggunaan sistem informasi tersebut.

Berdasarkan hasil penelitian tersebut, disarankan bagi pihak Universitas Udayana yang menyediakan sistem informasi IMISSU dengan tujuan membangun transparansi dan akuntabilitas di lingkungannya, agar terus berusaha melakukan pembenahan dan pengembangan atas sistem informasi yang sudah dibangun, guna meningkatkan kinerja organisasi. Bagi pihak yang terkait dengan penggunaan sistem informasi IMISSU diharapkan meningkatkan kemampuannya secara berkesinambungan, guna pemanfaatan sistem informasi IMISSU yang tersedia, dan berkeinginan untuk membangun kinerja yang lebih baik. 


\section{REFERENSI}

Alannita, Putu dan Suaryana, Gusti. 2014. Pengaruh Kecanggihan Teknologi Informasi, Partisipasi Manajemen, dan Kemampuan Teknik Pemakai Sistem Informasi Akuntansi pada Kinerja Individu. E-Jurnal Akuntansi. Universitas Udayana.

Al-Eqab, Mahmod and Dalia Adel. 2013. The Impact of IT Sophisticutions on the Perceived Usefulnes of Accounting Informasi Characteristics among Jordanian Listed Companies. International Journal of Business and Social Science, 4(3), pp: 143-155.

Alsarayreh, M.N.O.A.A., Jawabreh, M.M.F. Jaradat, dan S.A Alamro. 2011. Technological Impacth on Effectiveness of Accounting Information System (AIS) Applied by Aqaba Tourist Hotels. European Journal of Scientific Research. Vol 59. No. $3: 361-369$.

Baig, A. H. And Gururajan, R. 2011. Preliminry Study to Investigation the Determinants that Effe IS/IT Outsourcing. Journal of Information and Communication Technology Research, 1 (2), pp: 48-55.

Bailey, J. Dan Pearson, S. 1983. Development of a Tool For Measuring and Analyzing Computer User Satisfaction. Journal of Management Science 29 (5), pp: 153-154.

Baridwan, Zaki. 2009. Sistem Informasi Akuntansi. Edisi Kelima. Yogyakarta : BPFE. Bailey, J. Dan Pearson, S. 2008. Development of a Tool For Measuring and Analyzing Computer User Satisfaction. Journal of Management Science 29 (5), pp: 153-154.

Carter, V. Good. 1997. Dasar Konsep Pendidikan Moral. ALFABETA.

Cascio, Wayne F. (1992). Managing Human Resources: Productivity, Quality of Work Life, Profit. Singapore: McGraw-Hill International Editors.

Cho, Vincent dan Wong, James. 1997. Using a Service GAP Approach to Measure Managament Views Regarding The Effectiveness of The Hotel Accounting Information System. Journal of Contemporary Hospitality Management, 7(1) pp. 16-21.

Citramurti, Apsari. 2012. Penerapan Sistem Informasi Akuntansi dalam Efektivitas Pelaksanaan Pengendalian Intern Penjualan Jasa Perawatan Pipa Migas Pada PT. Tonsco International. Jurnal Akuntansi dan Bisnis Universitas Gunadarma. 
De Guinea, A.D., Kelley, H., dan Hunter, M.G. 2005. Information Systems Effectiveness in Small Business: Extending a Singaporean model in Canada. Journal of Global Information Management, 13,3: 55-70.

Dewi, Apriliana Ni Wayan. 2011. Pengaruh Tingkat Pendidikan, Pelatihan, dan Pengalaman Kerja Karyawan pada efektivitas Sistem Informasi Akuntansi Pada The Westin Resort Nusa Dua Bali. Jurnal Fakultas Ekonomi Universitas Udayana.

Dey, Shikha. 2007. Accounting Information System in Commercial Banks-An Evaluation in Bangladesh, The Bangladesh Accountant.

Edison, G., Manuere, F, Joseph, M., and Gutu, K. 2012. Evalition of Factors Influencing Adoption of Acounting Informasi by Small to Medium Enterprises in Chinhoyi. Journal of Contemporary Research in Bussiness, 4(6), pp: 1126-1141.

Efendi. Jap,. Elizabeth, V. And Murphy Smith. 2006. Information Technology and System. Research Published in Major Accounting Academic and Professional Journal.

Erayanti, Ni Putu. 2012. Pengaruh Insentif, Tingkat Pendidikan, Pelatihan dan Pengalaman Kerja Karyawan Terhadap Kinerja Individu Pengguna Sistem Informasi Akuntansi di KOPPAS Kumbasari-Badung. Jurnal Fakultas Ekonomi Universitas Udayana.

Fakhri, Husein dan Wibowo, Amin. 2005. Sistem Informasi Manajemen. Edisi Pertama. Yogyakarta: AMP YKPN.

Goodhue, D.L. 1995. Understanding User Evaluation of Informasi System. Journal Management Sciences. Desember, 1827-1844.

Gomes, Cardoso Faustino. 2003. Manajemen Sumber Daya Manusia. Yogyakarta. Penerbit: CV. Andi Offset.

Ghozali, Imam. 2009. Aplikasi Analisis Multivariate dengan Program SPSS, Edisi Keempat. Semarang: Penerbit Universitas Diponegoro.

Gorda, IGN. 2004. Manajemen Sumber Daya Manusia. STIE Satya Dharma Singaraja.

Hasibuan, Malayu S. P. 2008. Manajemen Sumber Daya Manusia. Jakarta: PT. Bumi Aksara. 
Heuer, Christian dan Travers, Mary Ann. K. 2010. FASB Issues New Accounting Standards for Bussiness administration. In Healthcare Financial Management Journal 64 (6):h: 40-43.

Holmes, S., and Nicholls, D. 1988. An Analysis of The Use of Accounting Information By Australian Small Business. Journal of Small Business Management.

Iranto, Dwi Bondan. 2012. Pengaruh Kepuasan Pengguna Sistem Informasi Terhadap Kinerja Individu (Studi Pada PT. PLN (Persero) Distribusi Jawa Tengah dan DIY. Jurnal Akuntansi Universitas Diponogoro.

Komara, Acep. 2006. Analisis Faktor-Faktor yang Mempengaruhi Kinerja Sistem Informasi Akuntansi. Jurnal MAKSI, Vol 6, No 2, 143-160.

Mangkuprawira, S. 2003. Manajemen Sumber Daya Manusia Strategik. Cetakan Kedua. Ghalia Indonesia, Jakarta.

Muhanna, Waled A dan Stoel, M. Dale. 2010. How do Investors Value IT? An Emprical Investigation of The Value Relevance of IT Capability and IT Spending Across Industries. In Journal of Information System 24 (1):h: 4366. American Accounting Association.

Mulyadi. 2001. Sistem Informasi Akuntasi Edisi Ke-3. Jakarta: Salemba Empat.

Manulang. 1984. Manajemen Personalia. Ghalia Indonesia : Jakarta.

Nicolaou, Andreas I. 2000. A contingency model of perceived effectiveness in accounting information systems: Organizational coordination and control effects. International Journal of Accounting Information Systems Volume 1, Issue 2, September 2000, Pages 91-105.

Radityo, Dody dan Zulaikha. 2007. Pengujian Model DeLone and McLean Dalam Pengembangan Sistem Informasi Manajemen (Kajian Sebuah Kasus). Jurnal Akuntansi Fakultas Ekonomi Universitas Diponegoro Semarang.

Rahmawati, Diana. 2008. Analisis Faktor-Faktor yang Berpengaruh Terhadap Pemanfaatan Teknologi Informasi. Jurnal Ekonomi dan Pendidikan, 5 (1), h: $107-118$.

Robbins, Stephen P. 2006. Perilaku Organisasi. Edisi Kesepuluh. Jakarta : PT. Indeks, Kelompok Gramedia.

Rolasmana, Meza. 2013. Pengaruh Gaya Kepemimpinan, Pengambilan Keputusan, Kompensasi Insentif Terhadap Efektivitas Sistem Informasi 
Akuntansi Pada Swalayan Di Tanjungpinang. Jurnal Akuntansi Fakultas Ekonomi Universitas Maritim Raja Ali Haji. Tanjungpinang.

Sajady. H,. Dastgir and H. Hashem Nejad. 2008. Evolutionof The Effectiviness of Accounting Information System. Intenatiomal Journal of Information Science and Technology, 6(2), pp: 49-59.

Salehi, Mahdi; Rostami Vahab; Mogadam Abdolkarim. 2010. Usefulness of Accounting Information System in Emerging Economy: Empirical Evidence of Iran. International Journal of Economics and Finance. pp: 186-195.

Soudani, S.N 2012. The Usefulness of an Accounting Information System for Effective Organisational Performance. International Journal of Economics and Finance. 4(5), pp: 136-145.

Sugiyono. 2013. Metode Penelitian Bisnis. Bandung: PT.Alfabeta.

Sutermeister, R.A, 1999. People and Producktivity. Toronto, Mc. Graw Hill Book.Co.

Syarfarudin, Alwi. 2001. Manajemen Sumber Daya Manusia Strategi Keunggulan Komparatif. Edisi Pertama. Yogyakarta. BPFE.

Utama, Suyana. 2010. Aplikasi Analisis Kuantitatif. Edisi Keenam. Denpasar: Fakultas Ekonomi dan Bisnis Universitas Udayana.

Wahyu, Kristiani. 2011. Analisis Pengaruh Efektivitas Teknologi Sistem Informasi Akuntansi Terhadap Kinerja Individual Pegawai PT. Kim Eng Sekuritas Indonesia. Jurnal Akuntansi Fakultas Ekonomi Universitas Gunadarma.

Wibowo. 2012. Manajemen Kinerja.Edisi Ketiga. Jakarta: Raja Grafindo Persada.

Widjajanto, Nugroho. 2001. Sistem Informasi Akuntansi. Yogyakarta : PT. Gelora Aksara Pratama. 


\title{
Lampiran Kuesioner
}

\author{
A. Data Responden \\ Nama \\ Jenis Kelamin* : Laki/Perempuan \\ Umur \\ Lama Bekerja \\ Jabatan \\ Pendidikan Terakhir* :
}

\section{Strata/S-2}

\section{Strata/S3}

1. Apakah Anda pernah menggunakan Sistem Informasi (program aplikasi)?*
$\square \mathrm{Ya}$
Tidak

2. Apakah Anda pernah mengikuti atau mendapatkan pelatihan mengenai teknologi sistem informasi?*
$\square \mathrm{Ya}$
Tidak

Keterangan :

* : Coret yang tidak perlu

* : Beri tanda $(\sqrt{ })$ pada pilihan jawaban yang Anda pilih

\section{B. Daftar Pertanyaan}

Berikan penilaian anda terhadap daftar pernyataan berikut dengan cara mengisi tanda centang $(\sqrt{ })$ atas jawaban yang Saudara/i anggap sesuai dengan kriteria berikut.

1. : Sangat Tidak Setuju (STS)

2. $\quad$ : Tidak Setuju (TS)

3. $\quad$ : Setuju $(\mathrm{S})$

4. $\quad$ : Sangat Setuju (SS) 


\section{Pengalaman}

\begin{tabular}{|c|c|c|c|c|c|}
\hline No & Pernyataan & STS & TS & $\mathbf{S}$ & SS \\
\hline 1 & $\begin{array}{l}\text { Anda memerlukan waktu yang cukup lama untuk } \\
\text { beradaptasi pada bidang yang baru anda tekuni. }\end{array}$ & & & & \\
\hline 2 & $\begin{array}{l}\text { Anda pernah bekerja pada departemen/bidang selain } \\
\text { pekerjaan Anda saat ini. }\end{array}$ & & & & \\
\hline 3 & $\begin{array}{l}\text { Anda mampu mengatasi kesalahan/kekeliruan } \\
\text { berdasarkan tujuan dan sistem informasi yang } \\
\text { digunakan dalam perusahaan. }\end{array}$ & & & & \\
\hline 4 & $\begin{array}{l}\text { Anda pernah melakukan kesalahan fatal pada } \\
\text { pekerjaan Anda sebelumnya. }\end{array}$ & & & & \\
\hline 5 & $\begin{array}{l}\text { Dalam menyelesaikan tugas, Anda memiliki } \\
\text { pengalaman yang cukup banyak sebagai seorang } \\
\text { yang ahli pada bidang tertentu. }\end{array}$ & & & & \\
\hline
\end{tabular}

Pelatihan

\begin{tabular}{|l|l|l|l|l|l|}
\hline No & \multicolumn{1}{|c|}{ Pernyataan } & STS & TS & S & SS \\
\hline 1 & $\begin{array}{l}\text { Program pelatihan yang Anda ikuti sudah sesuai } \\
\text { dengan pekerjaan/bidang saya. }\end{array}$ & & & & \\
\hline 2 & $\begin{array}{l}\text { Program pelatihan yang pernah Anda ikuti bermanfaat } \\
\text { bagi peningkatan kemampuan. }\end{array}$ & & & & \\
\hline 3 & $\begin{array}{l}\text { Banyak dampak positif yang Anda dapatkan dari } \\
\text { mengikuti pelatihan. }\end{array}$ & & & & \\
\hline 4 & Program pelatihan komputer sangat perlu dilakukan. & & & & \\
\hline 5 & $\begin{array}{l}\text { Anda pernah mengikuti pelatihan/kursus aplikasi } \\
\text { sistem informasi berbasis teknologi. }\end{array}$ & & & & \\
\hline 6 & $\begin{array}{l}\text { Anda termotivasi untuk mengikuti program pelatihan } \\
\text { agar mampu menciptakan kinerja yang lebih baik. }\end{array}$ & & & & \\
\hline
\end{tabular}

\section{Insentif}

\begin{tabular}{|l|l|l|l|l|l|}
\hline No & \multicolumn{1}{|c|}{ Pernyataan } & STS & TS & S & SS \\
\hline 1 & $\begin{array}{l}\text { Insentif yang Anda terima merupakan bentuk } \\
\text { penghargaan atas prestasi yang telah Anda capai. }\end{array}$ & & & & \\
\hline 3 & $\begin{array}{l}\text { Insentif yang Anda terima merupakan apresiasi atas } \\
\text { keberhasilan Anda menyelesaikan tugas. }\end{array}$ & & & & \\
\hline 4 & $\begin{array}{l}\text { Insentif yang diterima sudah memenuhi kebutuhan } \\
\text { minimal. }\end{array}$ & & & & \\
\hline 5 & $\begin{array}{l}\text { Insentif yang diterima sudah sesuai dengan beban } \\
\text { kerja Anda. }\end{array}$ & & & \\
\hline 6 & $\begin{array}{l}\text { Insentif yang Anda terima dapat memicu kinerja Anda } \\
\text { agar menjadi lebih baik. }\end{array}$ & & & \\
\hline
\end{tabular}

Efektivitas Penggunaan Sistem Informasi IMISSU 


\begin{tabular}{|c|c|c|c|c|c|}
\hline No & Pernyataan & STS & TS & $\mathbf{S}$ & SS \\
\hline 1 & $\begin{array}{l}\text { Mengakses data merupakan hal yang tidak sulit } \\
\text { dan tidak banyak memakan waktu. }\end{array}$ & & & & \\
\hline 2 & $\begin{array}{l}\text { Pengimplementasian sistem sudah menjadi hal } \\
\text { yang biasa bagi Anda. }\end{array}$ & & & & \\
\hline 3 & $\begin{array}{l}\text { Pekerjaan Anda lebih mudah dikerjakan bila } \\
\text { menggunakan sistem informasi IMISSU, } \\
\text { dibandingkan Anda mengerjakannya dengan } \\
\text { manual. }\end{array}$ & & & & \\
\hline 4 & $\begin{array}{l}\text { Kinerja Anda dinilai dengan laporan-laporan yang } \\
\text { dihasilkan melalui teknologi sistem informasi. }\end{array}$ & & & & \\
\hline 5 & $\begin{array}{l}\text { Penerapan program aplikasi yang ada dapat } \\
\text { menyediakan data yang cepat, tepat dan akurat. }\end{array}$ & & & & \\
\hline 6 & $\begin{array}{l}\text { Sistem informasi lebih mudah mendefinisikan } \\
\text { data yang Anda butuhkan. }\end{array}$ & & & & \\
\hline 7 & $\begin{array}{l}\text { Program aplikasi yang ada saat ini mendukung } \\
\text { pelaksanaan pekerjaan Anda. }\end{array}$ & & & & \\
\hline 8 & $\begin{array}{l}\text { Sistem informasi (IMISSU) yang ada, mampu } \\
\text { meningkatkan kinerja Anda. }\end{array}$ & & & & \\
\hline 9 & $\begin{array}{l}\text { Sistem informasi (IMISSU) yang ada dapat } \\
\text { meminimalisir waktu bekerja Anda. }\end{array}$ & & & & \\
\hline 10 & $\begin{array}{l}\text { Sistem informasi (IMISSU) pada perusahaan } \\
\text { Anda selalu dijaga kemutakhirannya. }\end{array}$ & & & & \\
\hline
\end{tabular}

\section{Saran/Pendapat yang ingin disampaikan}

Terima kasih atas Partisipasinya. 